\title{
Willingness to Pay for Electricity from Renewable Energy
}

Barbara C. Farhar and Ashley H. Houston

1617 Cole Boulevard

Golden, Colorado 80401-3393

A national laboratory of the

U.S. Department of Energy

Managed by Midwest Research Institute

for the U.S. Department of Energy

under Contract No. DE-AC36-83CH10093

Prepared under Task No. AS819620

September 1996 


\section{NOTICE}

This report was prepared as an account of work sponsored by an agency of the United States govemment. Neither the United States govemment nor any agency thereof, nor any of their employees, makes any warranty, express or implied, or assumes any legal liability or responsibility for the accuracy, completeness, or usefulness of any information, apparatus, product, or process disclosed, or represents that its use would not infringe privately owned rights. Reference herein to any specific commercial product, process, or service by trade name, trademark, manufacturer, or otherwise does not necessarily constitute or imply its endorsement, recommendation, or favoring by the United States govemment or any agency thereof. The views and opinions of authors expressed herein do not necessarily state or reflect those of the United States govemment or any agency thereof.

Available to DOE and DOE contractors from:

Office of Scientific and Technical Information (OSTI)

P.O. Box 62

Oak Ridge, TN 37831

Prices available by calling (423) $576-8401$

Available to the public from:

National Technical Information Service (NTIS)

U.S. Department of Commerce

5285 Port Royal Road

Springfield, VA 22161

(703) $487-4650$ 


\section{Preface}

This study was conducted in NREL's Center for Energy Analysis and Applications. It was sponsored by the Office of Planning and Assessment and the Office of Utility Technologies, Office of Energy Efficiency and Renewable Energy, U.S. Department of Energy.

The authors would like to thank the following reviewers who provided numerous helpful comments and suggestions: Paul Komor, E-Source; Ed Holt, Regulatory Assistance Project; Blair Swezey, NREL; Walter Short, NREL; and Kevin Porter, NREL. Special thanks are also expressed to Mary Anne Dunlap and Stuart Smoller for their editorial assistance and Kay Vernon for word processing support. Any inaccuracies are the responsibility of the authors. 


\section{Contents}

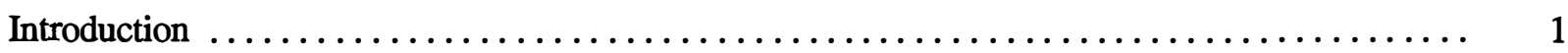

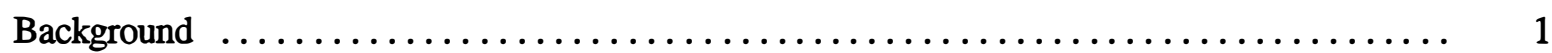

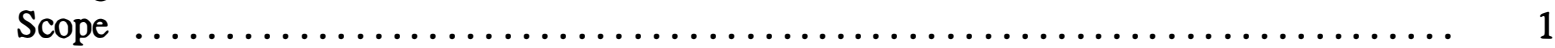

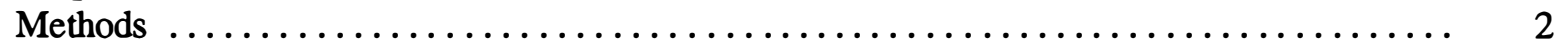

U.S. Public Preferences for Renewable Energy Technologies $\ldots \ldots \ldots \ldots \ldots \ldots \ldots \ldots \ldots \ldots$

Overall Willingness to Pay for Environmental Protection/Renewable Electricity $\ldots \ldots \ldots \ldots \ldots$

Utility Market Research on Willingness to Pay for Electricity from Renewables .......... 8

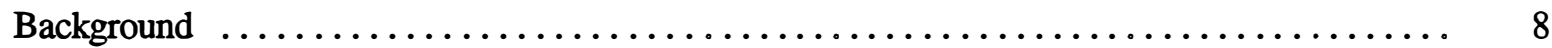

Results from Utility Company Market Research $\ldots \ldots \ldots \ldots \ldots \ldots \ldots \ldots \ldots \ldots \ldots . \ldots$

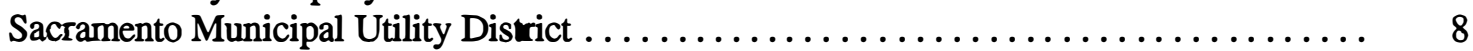

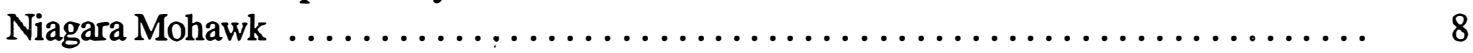

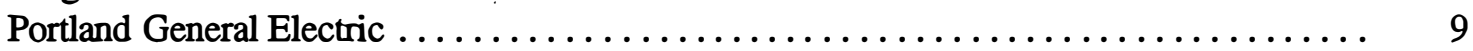

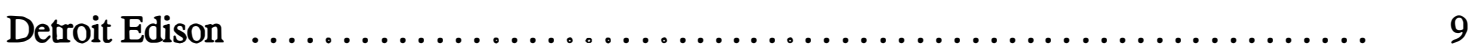

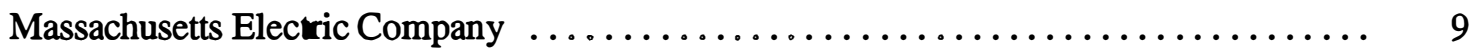

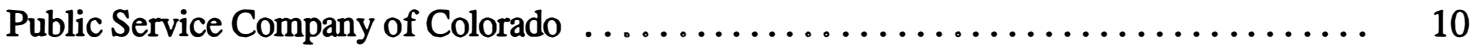

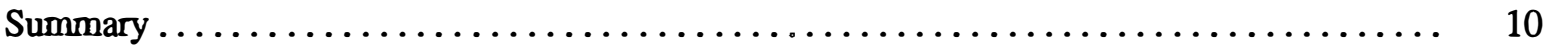

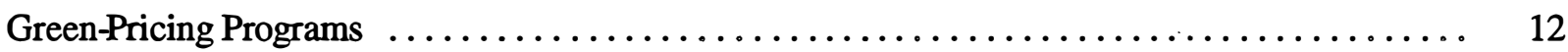

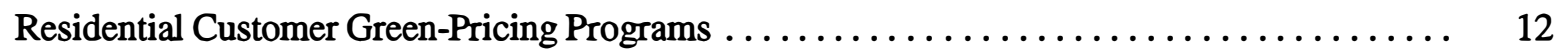

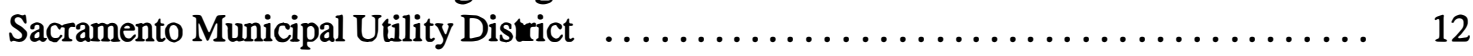

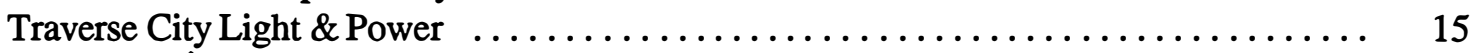

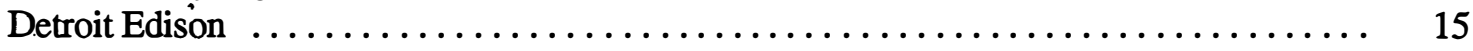

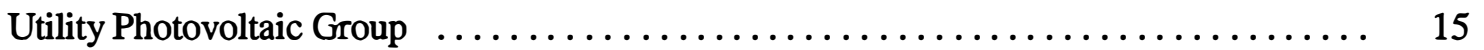

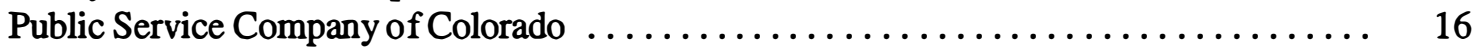

Wholesale Customer Green-Pricing Programs $\ldots \ldots \ldots \ldots \ldots \ldots \ldots \ldots \ldots \ldots \ldots \ldots \ldots$

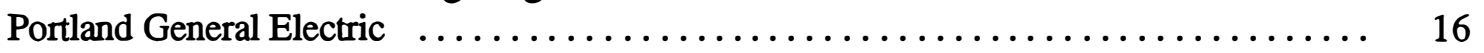

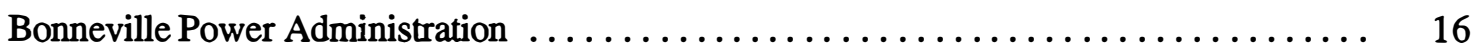

Other Green-Pricing Programs $\ldots \ldots \ldots \ldots \ldots \ldots \ldots \ldots \ldots \ldots \ldots \ldots \ldots \ldots \ldots \ldots \ldots \ldots$

Conclusions and Implications for Program Design and Future Research . . . . . . . . . . . . 19

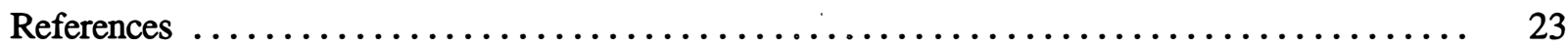

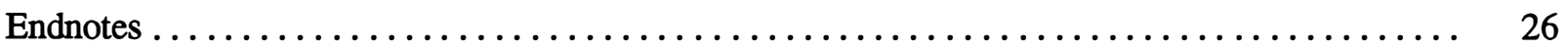




\section{List of Tables}

Page

1. Percentages Showing Comparative Preferences for Energy Sources on Several

Factors, 1993 ............................................

2. Percentages Willing to Pay Higher Prices to Protect the Environment, 1993-1994 ...... 5

3. Percentages Willing to Pay More for Less Environmentally Harmful Electricity,

1990-1994

4. Electricity Customer Groups Willing to Pay More for Decreases in

Unwanted Effects of Various Energy Mixes, as a Percentage of Customer Group

Average Monthly Electric Bill

5. Percentages of Customers Willing to Pay More for SMUD to Invest in

Renewable Resources

6. Residential Customer Green-Pricing Programs $\ldots \ldots \ldots \ldots \ldots \ldots \ldots \ldots \ldots \ldots \ldots$

7. Wholesale Customer Green-Pricing Programs $\ldots \ldots \ldots \ldots \ldots \ldots \ldots \ldots \ldots \ldots \ldots$

8. Average Monthly Amounts Paid and Kilowatt Production, Product-Specific v.

Contribution Green-Pricing Programs, 1996 


\section{Executive Summary}

National polls reveal widespread public preference and willingness to pay more for renewables. The public clearly prefers the idea of developing and using renewable energy over other energy alternatives. Utility companies, in the face of anticipated restructuring and increasing competition, are exploring how to aggregate widespread consumer preferences for electricity generation from renewable energy to protect and improve the environment. So-called "green pricing" programs attempt to capitalize on these preferences, and on an expressed willingness to pay more for environmental protection, through a variety of schemes designed to encourage electricity customers to pay specifically for renewable electricity or to contribute a voluntary pledge paid with their utility bills for the purchase of supply-side renewable energy.

This report explores the utility option of green pricing as a method of aggregating public preferences for renewables. It summarizes national data on public preferences for renewables and willingness to pay (WTP) for electricity from renewable energy sources; examines utility market studies on WTP for renewables and greenpricing program features; critiques utility market research on green pricing, and discusses experiences with selected green-pricing programs. The report draws inferences for program design and future research.

To summarize results from recent national surveys, approximately $40 \%$ to $70 \%$ of probability samples indicate they would pay a premium for environmental protection or for renewable energy. A clear distinction should be drawn between results from national opinion polls on the one hand and local-area market research findings on the other. The national poll data on preferences for renewable energy and WTP for environmental protection and electricity from renewable sources should be interpreted as a long-standing favorable predisposition toward renewables and a potential market that remains to be actualized. National poll evidence suggests that customers will notice and favor environmentally friendly electricity generation, whether or not they themselves participate in such programs. The specific percentages actually willing to participate in a given utility service territory should be defined by local-area market research.

The gap between what people say and what they do has been underscored by utility green pricing market research. Perhaps $10 \%$ of local area respondents say they will actually participate in a green pricing program, and, at a program's inception, perhaps only $1 \%$ will sign up. However, this does not mean that the public is unwilling to pay for renewable electricity. Limitations in utility market research, and in interpreting and using the data, may be contributing to the apparent discrepancy between stated and actual WTP noted so far. These limitations include (1) the proprietary nature of the data, (2) lack of scientific peer review, (3) data are not accumulating into a shared body of knowledge, (4) possibly inadequate sampling procedures, (5) inappropriate generalizing of findings, (6) errors or bias in data collection instruments, (7) inadequate pilot work as the basis for construction of data collection instruments, and (8) programs described to respondents may be designed to meet utility rather than customer needs. These problems have somewhat limited the usefulness of utility market research in greenpricing program design. Effective green-pricing program designs depend, at least in part, on the appropriate use of high quality market assessments.

Although utilities have little actual experience with green pricing programs, 24 utilities have investigated the concept and several have implemented programs. Utilities have taken two major approaches to program design: programs in which the utility (1) offers its customers a specific renewable electricity product at a premium price or (2) allows its customers an opportunity to contribute to a fund to be used in the future to pay for as-yetunspecified renewable electricity projects. Given the limited experience with these programs accumulated so far, the evidence suggests that programs in which customers pay a monthly premium for a specific renewable electricity product elicit a higher monthly financial commitment per customer than programs asking for contributions to unspecified future actions involving renewables.

The experience with green-pricing programs is summarized and factors likely to affect customer participation are identified. 


\section{Introduction}

\section{Background}

Public concern about the environment has increased during the past 12 years, and increasing majorities of the public have, in national opinion polls, selected renewable energy and energy efficiency over other energy altematives. In addition, national surveys show that majority concern for environmental protection extends even to personal costs. People seem willing to "Put their money where their mouths are"-at least up to a point. To protect and improve the environment, majorities in most surveys indicated a willingness to pay more for taxes, gasoline, electricity, other fuels, and automobiles. These survey items address institutional, rather than behavioral, ${ }^{1}$ responses to environmental protection. That is, they address willingness to pay (WTP) for actions on the part of government, the oil industry, utility companies, and automobile manufacturers.

Are the two trends-increasing environmental concern and preferences for renewables-linked? Evidence suggests that they are. Public preferences for policies and programs supportive of the development and use of renewables appear to be linked with perceived positive effects of renewables (including environmental protection) coupled with perceived negative effects of other energy alternatives. The salience of these strong preference trends as expressed in actual behavior, such as voting and purchasing renewable power, remains to be explored. Nationally, widespread preferences for renewable energy, and the reasons for it, suggest that large segments of utility customers might constitute a potential market for renewable electricity. But, there is a long distance between expressions of preference in the abstract and participation in a green-pricing program or directly purchasing renewable energy systems. Covering that distance depends on the actions of product manufacturers, utility companies, policy makers, and others involved in offering products to the buying public. This report explores the utility option of green pricing as a method of aggregating public preferences for renewables.

The green-pricing concept is based on the notion that premiums and contributions are needed for renewable electricity generation because, at least in the short nun, the market cost of generating electricity from renewables is higher than the market cost of generating electricity from such fuels as coal and natural gas. Green-pricing programs give customers the option of purchasing renewable energy at a higher price. Customers pay a monthly premium for a specific product or contributemore on their utility bills so that their utility companies can purchase renewables for electricity generation in the future. The issue of comparative generating costs and costing methods is beyond the scope of this report. Utilities, in an increasingly competitive environment, are interested in exploring the potential for green-pricing programs to build customer satisfaction and loyalty, even among those not participating in green-pricing programs. Some utilities have conducted market research in their service territories on WTP for renewable electricity; some have conducted field tests and simulations; and some have actually fielded green-pricing programs.

\section{Scope}

This report reviews the widespread national public support for renewable energy and WTP for environmental protection. It then reviews the available utility market research in local utility service territories on WTP, preferred characteristics of green-pricing programs, and projected levels of participation in such programs. Fieldtested green-pricing programs and theirparticipation rates are described, and implications for future research and green-pricing-program design are discussed. 


\section{Methods}

This analysis is based on work that updates earlier studies identifying patterns of public opinion about energy. Items that are included in this report represent patterns of response found in a set of data from more than 700 polls of national probability samples. This secondary analysis relies on poll data from library collections, polling organizations, and the Roper Center for Public Opinion Research database (accessed through the DIALOG Information Retrieval Service). The national data examined were derived from probability samples of U.S. adults, registered voters, or electricity customers queried by major polling organizations, such as Roper, Harris, Gallup, and Cambridge Research. In addition, to collect utility market data, we contacted utility market analysts and requested copies of their studies. We also reviewed published articles and contacted utility managers of green-pricing programs to gather program descriptions and information on their experience with green-pricing programs. 


\section{U.S. Public Preferences for Renewable Energy Technologies}

An analysis of poll data from 1979 through 1992 offered considerable evidence that, when other energy alternatives are included in survey items and cost or price information is not, renewable energy and energy efficiency have been the public's preferred energy alternatives since 1977 (Farhar et al. 1979, 1980; Farhar 1993; Farhar 1994). The data showed a decrease in public preferences for fossil fuels (except natural gas) and majority opposition toward further implementation of nuclear energy. A key question is: Has this trend continued despite the changes in the political climate expressed in the 1994 congressional election? Evidence shows that it has. Results from national surveys since the 1994 election show continued public preferences for efficiency and renewables over other energy alternatives. Some examples reflecting this trend are presented here.

In December 1994, RSM, Inc. (Breglio 1994) asked a national probability sample of registered voters: "If the government is to continue funding for research and development for specific energy sources, which source do you think should be highest priority? Renewable energy, like solar, wind, geothermal, biofuels, and hydroelectric; energy efficiency and conservation technologies; nuclear energy; fossil fuels like oil and coal; or natural gas? And which source do you think should be the second highest priority?" A plurality of $42 \%$ selected renewable energy as highest priority; $22 \%$ selected energy efficiency and conservation; $15 \%$ natural gas; $9 \%$ nuclear energy; $7 \%$ fossil fuels (oil and coal); and 6\% did not know. When asked their second choice, $27 \%$ selected energy efficiency and conservation; $22 \%$ renewable energy; $20 \%$ natural gas; $12 \%$ fossil fuels; $12 \%$ nuclear energy; and $7 \%$ did not know. Eighty-five percent of the respondents agreed that "The federal government should continue to support partnerships with American business to promote sales of energy efficiency and renewable energy technologies through research and development and programs to open new domestic and international markets." Political party affiliation made no difference in preferences for renewables and efficiency.

A year later, in December 1995, RSM, Inc. again asked registered voters which of five energy research and development programs should receive the highest priority for funding in DOE's budget as Congress and the Administration worked to reduce the federal deficit (Sustainable Energy Budget Coalition 1996). A plurality of $34 \%$ selected "renewable energy involving solar, wind, geothermal, biomass, and hydroelectric power"; $21 \%$ "technologies to improve energy efficiency and conservation"; $9 \%$ selected each of nuclear power, fossil fuels (such as oil, gasoline, and coal), and natural gas; and 19\% did not select any of the choices.

This pattern of public preference for the development and use of renewable energy continues a trend of some 18 years' duration - one of the strongest patterns and longest-lasting trends observed in the entire data set on public preferences on energy and environmental policy. But the question remains: Will products and services be created that will satisfy the public preference for the development and use of renewable energy? 


\section{Overall Willingness to Pay for Environmental Protection/Renewable Electricity}

Why does the public prefer efficiency and renewables? Concem for the environment has been increasing (Dunlap 1991; Dunlap and Scarce 1991; Farhar 1994). Energy-supply preferences seem increasingly to be environmentally driven (Farhar 1994). Preferences for renewable energy and energy efficiency are consistent with increasing environmental concems (with the greenhouse effect, oil spills, nuclear accidents, and radioactive waste disposal problems). This trend appears to be continuing. For example, in July 1994, $61 \%$ of a national sample believed that the following statement was "definitely true" or "probably true": "Every time we use coal or oil or gas, we contribute to the greenhouse effect" (National Opinion Research Center 1994).

Concem for the environment is not the only reason for preferences for renewable energy. In July 1993, a national sample was asked: "I'm going to read you a list of sources for energy. Then I'll give you a description and I'd like you to tell me which one energy source from the list you feel most closely matches that description. The energy sources are: solar, oil and gasoline, natural gas, nuclear, hydroelectric (water power), and coal. Now, of those energy sources I just listed, which one do you feel is . . .?" (Wirthlin Group 1993). Table 1 shows the results.

Table 1. Percentages Showing Comparative Preferences for Energy Sources on Several Factors, 1993

\begin{tabular}{llcccccc} 
Factor & Solar & $\begin{array}{c}\text { Hydro- } \\
\text { electric }\end{array}$ & $\begin{array}{c}\text { Natural } \\
\text { gas }\end{array}$ & $\begin{array}{c}\text { Oil \& } \\
\text { gasoline }\end{array}$ & $\begin{array}{c}\text { Nuclear } \\
\text { Coal }\end{array}$ & $\begin{array}{c}\text { Don't } \\
\text { know }\end{array}$ \\
\hline Best for environment & 55 & 22 & 12 & 3 & 3 & 3 & 2 \\
Safest & 50 & 24 & 12 & 3 & 2 & 6 & 3 \\
Most abundant & 29 & 18 & 16 & 15 & 6 & 11 & 4 \\
$\begin{array}{l}\text { Makes the U.S. } \\
\quad \text { most self-reliant }\end{array}$ & 22 & 16 & 18 & 8 & 20 & 9 & 7 \\
Least expensive & 32 & 17 & 19 & 6 & 4 & 15 & 6 \\
$\begin{array}{l}\text { Best for U.S. economy } \\
\text { Most positive for you }\end{array}$ & 25 & 18 & 19 & 15 & 11 & 7 & 5 \\
$\quad \begin{array}{l}\text { Will play increasing role } \\
\text { in 21st century }\end{array}$ & 34 & 22 & 22 & 11 & 5 & 3 & 3 \\
\hline
\end{tabular}

Source: Constructed by the authors using data from the Wirthlin Group (1993)

What have polls shown about the overall WTP for environmental protection and renewable electricity? In several national polls, majorities of $57 \%$ to $80 \%$ said they were willing to pay more for electricity produced in a cleaner way or from sources less harmful to the environment (studies cited in Farhar 1994). Laboratory experiments show that subjects using real money will contribute between $20 \%$ and $40 \%$ of their true WTP for provision of a public good (studies cited in Schulze 1994). Individuals exhibit a natural tendency to cooperate to make everyone better off, even though each individual has an incentive to ride free. Percentages expressing WTP tend to be higher in surveys (which reflect hypothetical situations) than in real situations. Traditional market research methods can test acceptability of alternative product offerings but cannot test alternative mechanisms for overcoming free riding (Schulze 1994).

In 1993 and again in 1994, the National Opinion Research Center asked: "How willing would you be to pay much higher prices in order to protect the environment?" Table 2 shows the findings from the 2 years. 
Table 2. Percentages Willing to Pay Higher Prices to Protect the Environment, 1993-1994

\begin{tabular}{lcc}
\multicolumn{1}{c}{ Willing to Pay } & 1993 & 1994 \\
\hline Very willing & 11 & 9 \\
Fairly willing & 42 & 37 \\
Don't know/Neither & 25 & 27 \\
Not very willing & 15 & 17 \\
Not at all willing & 7 & 9 \\
\hline
\end{tabular}

Source: Constructed by the authors using data from the National Opinion Research Center (1994)

In September 1990 and again in May 1994, Cambridge Reports/Research International asked: "How much more would you personally be willing to spend each month to have your electricity come from sources that are less harmful to the environment?" The response options prevent disceming those who would pay nothing at all, because the first option was $\$ 0$ to $\$ 5$. Table 3 shows the trend in responses.

Table 3. Percentages Willing to Pay More for Less Environmentally Harmful Electricity, 1990-1994

\begin{tabular}{lcc} 
Amount More Willing to Pay & $9 / 90$ & $5 / 94$ \\
\hline \$0-5/month & 22 & 40 \\
$6-10$ & 29 & 20 \\
$11-20$ & 21 & 18 \\
$21+$ & 26 & 22 \\
\hline
\end{tabular}

Source: Constructed by the authors using data from Cambridge Reports/

Research International (1994)

These data show that pluralities still express WTP to protect the environment and to generate electricity from environmentally beneficial sources; however, they also suggest that percentages expressing WTP may have decreased slightly in the 4 years from 1990 to 1994.

In May 1995, the Harris poll asked: "How willing would you be to pay somewhat higher electricity costs if you knew the money would be spent to protect and restore endangered species-very willing, somewhat willing, not very willing, or not willing at all?" Sixty-one percent said they would be "very" or "somewhat" willing; $39 \%$ would be unwilling to pay higher electricity costs for this purpose.

In May 1995, Cambridge Energy Research Associates and Opinion Dynamics Corporation reported that 20\% of electricity customers said they would pay a 30\% premium for solar electricity (Solar Letter 1995). If an "economic penalty" were removed, $72 \%$ said they would either definitely or probably "participate in a program that allowed customers to choose their source of generated power." Unlike most other studies, this study showed an ideological bias toward renewables, with liberals twice as likely as the overall public to be interested and the 
elderly half as interested as younger respondents. This study showed that neither income nor education made a difference in WTP.

In December 1995, RSM, Inc. asked "Suppose you have the chance to choose your electric company the same way you now can choose your long-distance telephone company and the choice were between a utility company that uses coal to generate electricity and a utility company that produces electricity with cleaner, but slightly more expensive, renewable energy sources. Of the following, which indicates how much more you would be willing to spend per month for electricity generated from cleaner renewable sources?" (Sustainable Energy Budget Coalition 1996). A plurality of $49 \%$ said they would pay at least up to $2 \%$ a month more; $19 \%$ up to $10 \%$ more; and $8 \%$ more than $20 \%$ more. Twenty-four percent said they would not pay more and $1 \%$ did not know.

Two relevant statewide surveys were also located. Wood et al. (1995), sampled Wisconsin electricity customers (stratified by residential, farm, small commercial, large commercial, and industrial users). ${ }^{2}$.Wisconsin respondents were asked to weigh trade-offs between attributes related to health, environment, and other effects associated with a mix of energy sources and to state preferences for attribute levels. Using an ordered-probit model, ${ }^{3}$ the analysts found that stated WTP overstates customers' actual WTP. Stated WTP should be interpreted as an index of customers' relative preferences for certain outcomes over other outcomes. Paying more and paying the same with differing effects are two possible outcomes. All customer groups were willing to pay more for certain effects. Table 4 shows some interesting examples of these results.

\section{Table 4. Electricity Customer Groups Willing to Pay More for Decreases in Unwanted Effects of Various Energy Mixes, as a Percentage of Customer Group Average Monthly Electricity Bill}

\begin{tabular}{lcccc}
$\begin{array}{l}\text { Willing to Pay More } \\
\text { for a Decrease in: }\end{array}$ & Residential & $\begin{array}{c}\text { Small } \\
\text { Commercial }\end{array}$ & $\begin{array}{c}\text { Large } \\
\text { Commercial }\end{array}$ & Industrial \\
\hline Number of cancer cases (1 case) & 3.56 & 1.79 & 2.42 & 1.95 \\
$\begin{array}{l}\text { Number of major appliance use } \\
\text { restrictions }\end{array}$ & 2.73 & 1.10 & 2.33 & 1.79 \\
$\begin{array}{l}\text { Number of fish consumption bans } \\
\text { (per lake) }\end{array}$ & 1.17 & 0.67 & 1.44 & 0.90 \\
$\begin{array}{l}\text { Number of annual respiratory cases } \\
\text { (per 100 cases) }\end{array}$ & 0.40 & 0.26 & 0.28 & 0.46 \\
$\begin{array}{l}\text { Acres of land required per MW } \\
\text { (per acre) }\end{array}$ & 0.38 & 0.15 & 0.25 & 0.28 \\
\hline
\end{tabular}

Source: Constructed by the authors using data from Wood et al. (1995)

Wood et al. concluded that customers need education on alternative mixes of energy and their costs, benefits and effects; that customers want utilities to protect the environment; that customers do not want use restrictions and load-control programs; and that customers should be included in utility planning.

A 1994 study of North Dakota residents found that 83\% said "developing renewable resources such as solar and wind is as important as the development of fossil energy resources, such as oil, coal and natural gas." Sixty-one percent said they would pay more for electricity generated from renewable resources; $34 \%$ said they would not 
(Harmon and Wind 1995). Nineteen percent said they would pay $\$ 0-\$ 5$ a month more; $45 \%$ said $\$ 6$ to $\$ 10 ; 11 \%$ said $\$ 11$ to $\$ 15 ; 7 \%$ said $\$ 16$ to $\$ 20$; and $9 \%$ said $\$ 21$ or more; and $9 \%$ were unsure.

To summarize results from recent national and state surveys (using various item wordings on WTP), approximately $40 \%$ to $70 \%$ indicate they would pay a premium for environmental protection or for renewable electricity. Bymes et al. (1995) argued that opinion polls are in error because they found, in their Denver-area market research, much lower percentages actually willing to pay more for renewable electricity. We need to draw a clear distinction between results from national polls and local market research. The national poll data on preferences for renewable energy and WTP for environmental protection and for electricity from renewable resources should be interpreted as a long-standing public interest in and generally favorable predisposition toward renewables, and a potential market that remains to be actualized. To put it another way, if majorities were indicating lack of interest in renewables and unwillingness to pay a premium for renewable electricity, utilities would not be interested in attempts to develop green-pricing programs. The poll evidence supports the notion that customers will notice and favor environmentally friendly electricity generation, whether or not they themselves participate in such programs. The specific percentages actually willing to participate in a given utility service territory should be defined by local-area market research. 


\section{Utility Market Research on Willingness to Pay for Electricity from Renewables}

\section{Background}

Most market research conducted by utilities is considered proprietary; therefore, methods employed, sampling frames and methods, the questions used, frequency distributions of responses, and other analyses are generally not published. This makes it difficult to assess the quality of market research on green pricing. It also interferes with accumulating a reliable body of knowledge about green-pricing market research results that could help in program design and policy formulation. Utility market research may not be subjected to as rigorous a peer-review process as more publicly available scientific research undergoes.

\section{Results from Utility Company Market Research}

By contacting numerous utility companies and perusing the literature, we were able to gather some market research information on green-pricing programs from six utility companies. Although these studies usually do not present enough information on methods and responses to evaluate their quality, we include them for the information they have presented and to evaluate them in the context of other findings presented in this report and elsewhere. The six utilities are: (1) Sacramento Municipal Utility District, (2) Niagara Mohawk, (3) Portland General Electric, (4) Detroit Edison, (5) Massachusetts Electric Company, and (6) Public Service Company of Colorado.

\section{Sacramento Municipal Utility District}

A 1993 survey of Sacramento citizens showed that $26 \%$ of the general population [32\% of EV Pioneers (electric vehicle owners) and $57 \%$ of the "green population"] expressed willingness to pay a $15 \%$ premium for PV electricity from their rooftops (Osbom and Collier 1994). The WTP percentages were higher when a $15 \%$ premium was offered with "rate stabilization"--49\% of the general population, 55\% of EV Pioneers, and 77\% of the green population. Seventy percent of the general population, 74\% of EV Pioneers, and $88 \%$ of the green population expressed WTP a 1\%-10\% premium "to establish a Clean Energy Program" (not necessarily on their rooftops).

As part of its integrated-resource-planning process, the Sacramento Municipal Utility District (SMUD) surveyed 800 residential, business, and industrial customers in February 1995. The results showed that $48 \%$ of residential, $49 \%$ of business, and $32 \%$ of industrial customers expressed WTP for "investments in renewable resources." Rating "promoting renewable energy production" as important were $72 \%$ of residential, $72 \%$ of business, and $32 \%$ of industrial customers. Willingness to pay more for SMUD to invest in renewable resources was measured for the different customer groups by percentage premium. Table 5 presents the results.

\section{Niagara Mohawk}

In 1994, Niagara Mohawk (NiMo) found that some customers were willing to pay up to $\$ 10$ a month more for renewable electricity "if they could see some common good from the program." NiMo concluded that only "green" customers appeared to place a significant value on NiMo buying renewable fuels or constructing renewable facilities. Green program characteristics favored were a fixed-amount payment for a green rate and a monthly or bimonthly rather than an annual payment. Customers also preferred flexibility-a 1- to 3-year commitment or the ability to drop out at any time (Bauman 1994). A later telephone survey of 900 customers supplemented by conjoint interviews with a subsample of 116 showed the following results. Customers thought that using renewables to generate electricity was a good thing for NiMo to do, even if they didn't participate. 


\section{Table 5. Percentages of Customers Willing to Pay More for SMUD to Invest in}

Renewable Resources

\begin{tabular}{lccc} 
Customer Groups & Residential & Business & Industrial \\
\hline $5 \%$ more & 43 & 38 & 8 \\
$10 \%$ more & 27 & 20 & 0 \\
$15 \%$ more & 16 & 10 & 0 \\
$20 \%$ more & 7 & 3 & 0 \\
\hline
\end{tabular}

Source: Constructed by the authors using data from the Sacramento Municipal Utility District (1995)

"Green" respondents were more likely than others to say they would pay a $\$ 6 /$ month premium for renewable electricity (mean score of 2.7 on a scale of $1-5$ where $5=$ very likely); at $\$ 3 /$ month their mean score was 3.6. "Non-green" respondents scored 1.8 at $\$ 6 /$ month and 2.6 at $\$ 3 /$ month, respectively. The expected level of participation depended on awareness; for a period of 3 years at $\$ 6 /$ month at $10 \%$ awareness, $6 \%$ of the total population was projected to adopt. At $30 \%$ program awareness, $19 \%$ of the total population was projected to adopt.

\section{Portland General Electric}

Portland General Electric (PGE) conducted market research on several green-pricing options to assess customer response. PGE examined three programs through market research (lock-in electric rates for wind; Oregon taxfree bonds; and an affinity "Share-the-Wind" Visa credit card) and field-tested two approaches (the Share-theWind credit card and a "Penny Jar" bill roundup program) (Weijo and Boleyn 1996). Based on the results, at $65 \%$ program awareness, PGE estimated the following market penetrations: $2 \%$ for lock-in electric rates; $1.2 \%$ for tax-free bonds; $1.3 \%$ for the affinity credit card; and 3\% for the Penny Jar program. The researchers recommended that PGE offer a full line of green-marketing products with these four components to reach the maximum number of customers possible.

\section{Detroit Edison}

Overall, market research by Detroit Edison (DE) showed a $30 \%$ willingness to pay $\$ 10$ to $\$ 20$ /month more for renewable electricity, which translated to a projected $1 \%$ penetration. DE has not published market research results in detail, considering them proprietary.

\section{Massachusetts Electric Company}

Customer focus groups at Massachusetts Electric Company (MECo) showed enthusiasm for renewables and green-pricing concepts. However, customers were also concerned about costs, and some distrusted the utility's real motives for involvement. A subsequent telephone survey of 400 electricity customers showed that $49 \%$ expressed WTP at a 5\% premium; $32 \%$ at $10 \%$; and $13 \%$ at $20 \%$. A follow-up mail survey of 100 customers (who said they would participate or didn't know) generated $15 \%$ who said they would definitely participate, and 24\% who said they probably would (Green Pricing Newsletter 1995). ${ }^{4}$ 


\section{Public Service Company of Colorado}

Focus-group research in 1992 established that Public Service Company of Colorado (PSCo) customers had strong feelings about the environment and the nation's natural resources. Telephone interviews tested program features. Respondents wanted more renewable energy development, but disliked the term "green pricing," which was associated with "green-marketing" efforts for other products. In response to these results, PSCo changed the program's name to "Eco-Option," then to "Voluntary Renewable Energy Program," and next to "Renewable Energy Altematives Program (REAP)." By late 1995, PSCo referred to the program as the "Renewable Energy Trust Fund." In 1996, it became the "Renewable Energy Trust."

Contingent valuation (CV) methodology was used to predict customer participation in a PSCo green-pricing program at specified pricing levels (Baugh, Bymes, and Jones 1994). Initial customer support was reflected in the $82 \%$ who said they were willing to pay $\$ 1-\$ 4 /$ month more to voluntarily support the development of renewable energy. At the first trials, $75 \%$ took registration cards to pledge $\$ 2 /$ month; $10 \%$ signed and returned the cards. The average per-customer participation cost was less than $\$ 2 /$ month or approximately $5 \%$ of an average customer's electric bill.

PSCo's program was viewed positively by more than $80 \%$ of respondents, regardless of their personal participation. Retrofit hydropower, photovoltaics (PV), wind, and solar thermal projects were "well accepted" (Electrical World 1993; Baugh, Bymes, and Jones 1994). Respondents said that it was appropriate for PSCo to make a profit on a renewables program. A majority reportedly agreed that it was better to have PSCo develop renewables than the state or federal government.

In a critical review of the PSCo research, Marcus et al. (1995) said that the CV analysis used age and education as independent variables predicting WTP. The reasons underlying these analytic choices have not been made clear; other research would not necessarily support them. The PSCo market research did not describe the variables used in the analysis nor report the variance explained. This prevented others from assessing the validity of the study's underlying assumptions and analyses.

\section{Summary}

Identifying segments of the population as green-pricing customers is not yet possible from the limited data and inconsistent findings available. More demographic analyses need to be completed for definitive pattems to emerge. Preliminary findings suggest that "green" customers (for example, those contributing or belonging to environmental organizations) are willing to pay more than others for fossil fuel replacement and environmentalbenefit attributes (Bauman 1994). Green customers have higher adoption "probabilities" than others for renewables and emission-allowance programs (Bauman 1994). In addition, findings are mixed on the relationship of political ideology and age to WTP (see, for example, Energy Services Marketing Letter 1995 on the Niagara Mohawk findings that green-program participants are older). Income and education so far appear to be unrelated to WTP (for example, see the Solar Letter 1995 report).

Major problems exist in assessing the results of utility market research data.

1. Because such data are considered proprietary, the items used and the actual range of responses are rarely published. Instead, interpretations are published. Therefore, the scientific quality of the research and of the interpretations is impossible to assess because the publications describing the findings do not undergo rigorous peer review. In addition, the data are not accumulating into a shared body of knowledge.

2. Sometimes the interpretations offered generalize inappropriately to populations of electricity customers. For example, market researchers have, on occasion, generalized from percentages of focus-group participants expressing an opinion to the service-area population. 
3. Often, sampling procedures are not described; therefore, the reader has no information on sampling criteria and sampling frames used. The generalizability of the findings cannot be assessed. Some writers have reported that they included only "green customers" in the study, but they then generalized results to the population of electricity customers in the utility's service territory. Such generalizations are inappropriate.

4. Programs described to respondents in market research may be actual or hypothetical. However, they may be designed more to meet the utility company's needs than those of customers. If a low proportion of customers participate in a program, it may mean that the program offered is not designed to meet customers' needs rather than that customers are not willing to pay for renewable electricity.

5. Question phrasing is often a problem. For example, asking respondents "Are you willing to pay more for electricity generated from renewable sources such as solar and wind power?" is different from asking them, "Will you pay $\$ 5 /$ month more on your utility bill each month so that XYZ utility can generate renewable electricity?"

6. Utilities may be missing other possible key motivators. Environmental protection is an important element of renewable electricity, but other factors such as health and safety can also play a part in favorability toward energy sources (for example, see responses in Tables 1 and 4). 


\section{Green-Pricing Programs}

The next issue to be addressed is the translation of the public's preferences and WTP into actual participation in programs that utilities are currently offering. Based on current market research and on the desire of utility decision makers to design programs that provide attributes customers value, utilities have implemented or are planning green-pricing programs that enable customers to pay a premium rate for specific renewables products or to contribute to the future development of renewable power projects. The concept of green pricing was originally discussed by Moskovitz (1993); utilities have little actual experience with green-pricing programs, yet 24 utilities $^{5}$ have investigated the concept with several moving forward with implementation.

Utilities have taken two major approaches to program design: programs in which the utility (1) offers its customers a specific renewable electricity product at a premium price or (2) allows its customers an opportunity to contribute to a fund to be used in the future to pay for as-yet-unspecified renewable electricity projects.

Some utilities have programs that aim to develop renewables in general, whereas others focus on developing a single type of renewable technology. Still others support a specific project that the utility wishes to develop, but could not finance otherwise. Programs to date include wind and geothermal resources, both on- and off-grid applications for PV, and rates for both residential and wholesale customers. Table 6 briefly describes five residential green-pricing programs actually implemented, and five more in the planning stage. Key program elements include length of customer commitment to the program, sense of exposure to risk, and perceived value added by the program.

\section{Residential Customer Green-Pricing Programs}

\section{Sacramento Municipal Utility District}

SMUD's PV Pioneers Program started in 1993 and is probably the most widely known green-pricing program. The program's purpose is to develop the experiential base needed to successfully integrate PV into their utility system and to hasten the processes necessary to make PV more cost effective. As of early 1996, 350 residential customers were participants in the program for a total of 1216 kilowatts of PV power; 100 new residential customers are being added to the program each year (MoCorkle 1996). When SMUD first offered its PV Pioneer Program in 1993, 2000 of the total 421,279 residential customers responded; 600 passed the screening and agreed to pay a premium on their utility bills. SMUD continues to get approximately 1000 responses each year to its program solicitations (Osborn and Collier 1994).

SMUD's residential customers can elect to pay a $\$ 4$ flat fee on their monthly utility bills over a 10 -year period for a 4-kilowatt, grid-connected rooftop PV panel. SMUD purchases, owns, and installs the systems and is responsible for their operation and maintenance. When the program began in 1993, the price of PV for this program was $\$ 7.70$ per watt. In 1996 , the price has dropped to $\$ 5.98$ per watt, showing that the PV Pioneers program has had a measurable effect on the commercialization of PV (Osborn and Collier 1994). As an incentive to participate, PV Pioneers are guaranteed no rate increase on the PV power for 10 years.

In 1995, SMUD began a PV Pioneers Program for commercial customers. Thus far, five area churches have elected to participate. Because they are not required to pay the green-pricing premium, nonprofit organizations such as these churches are in essence donating space on their roofs to the program. 


\begin{tabular}{|c|c|c|}
\hline Utility & Program & Notes \\
\hline $\begin{array}{l}\text { Sacramento Municipal Utility } \\
\text { District }\end{array}$ & $\begin{array}{l}\text { The PV Pioneers Program is a program in which customers } \\
\text { pay a flat } \$ 4 \text { monthly fee over } 10 \text { years to have a } 4-\mathrm{kW} \text {, grid- } \\
\text { connected PV panel installed on their roofs. }\end{array}$ & $\begin{array}{l}\text { Total participation as of January } 1996 \text { was } 350 \text { customers } \\
\text { for a total of } 1216 \mathrm{~kW} \text {, with } 1,000 \text { new customer responses } \\
\text { each year (Osborn and Collier 1996; McCorkle 1996). }\end{array}$ \\
\hline $\begin{array}{l}\text { Public Service Company of } \\
\text { Colorado }\end{array}$ & $\begin{array}{l}\text { The Renewable Energy Trust (RET) is a program in which } \\
\text { customers make voluntary monthly pledges in support of the } \\
\text { accelerated growth of renewables. This program includes the } \\
\text { Round Up for Renewables Program in which the rounded-up } \\
\text { portion of the customer's monthly bill is added to the Trust. }\end{array}$ & $\begin{array}{l}14,000 \text { customers participate in the RET, at an average } \\
\text { pledge of } \$ 2 \text { per month. Approximately } \$ 158,000 \text { has } \\
\text { been collected per year and has been used to fund small } \\
\text { stand-alone PV projects (Green Pricing Newsletter } 1994 \\
\text { and Denver Post 1996). }\end{array}$ \\
\hline Detroit Edison & $\begin{array}{l}\text { The "Solar Currents" program offers solar energy service to } \\
\text { residential and small commercial customers for an additional } \\
\$ 6.59 \text { per month, on average, for each } 100 \text { watts of service } \\
\text { from a planned } 28.4-\mathrm{kW} \text { PV facility. }\end{array}$ & $\begin{array}{l}\text { Federal funding is being provided through the UPVG's } \\
\text { TEAM-UP effort. As of January } 1996,248 \text { residential and } \\
\text { commercial customers had signed up to participate. }\end{array}$ \\
\hline Traverse City Light and Power & $\begin{array}{l}\text { Residential customers make a } 3 \text {-year commitment, while } \\
\text { commercial customers make a } 10 \text {-year commitment to pay a } \\
\text { premium of } 1.58 \text { cents } / \mathrm{kWh} \text { (approximately } \$ 7.50 \text { per month } \\
\text { for residential) to fund construction of a } 600-\mathrm{kW} \text { wind } \\
\text { turbine. The program began in the spring of } 1996 .\end{array}$ & $\begin{array}{l}\text { Participation is currently } 145 \text { residential and } 20 \text { com- } \\
\text { mercial customers out of } 8,000 \text { customers with additional } \\
\text { customers on a waiting list (Smiley 1995). An incentive } \\
\text { for participation is a guarantee of no rate increases due to } \\
\text { fuel cost increases over the period of participation. }\end{array}$ \\
\hline $\begin{array}{l}\text { City of Anaheim, City of Austin, } \\
\text { AZ Public Service, Central \& } \\
\text { Southwest, Detroit Edison } \\
\text { (mentioned above), NYSEG, } \\
\text { Northern States Power, WI } \\
\text { Public Service }\end{array}$ & $\begin{array}{l}\text { These eight utilities are participating in the Utility } \\
\text { Photovoltaic Group (UPVG) TEAM-UP PV Friendly Pricing } \\
\text { program. They will install } 347 \mathrm{~kW} \text { of grid-connected PV } \\
\text { systems on residential and commercial buildings. The } \\
\text { projects will be financed using green-pricing schemes } \\
\text { developed individually by each of the utilities. }\end{array}$ & $\begin{array}{l}\text { TEAM-UP will be providing } \$ 1.4 \text { million in funds to the } \\
\text { eight utilities (National Renewable Energy Laboratory and } \\
\text { Photovoltaics for Utilities 1995; The Solar Letter 1996). }\end{array}$ \\
\hline
\end{tabular}

Source: Constructed by authors using data from citations in text of table. 
Table 6. Residential Customer Green-Pricing Programs (Planned But Not Yet Implemented) (Continued)

\begin{tabular}{|c|c|c|}
\hline Utility & Program & Notes \\
\hline Florida Power Corporation & $\begin{array}{l}\text { Florida Power Corporation will be implementing the Solar } \\
\text { for Schools program in which a variety of solar energy } \\
\text { technologies will be installed in area public schools using } \\
\text { customer contributions leveraged with utility funding. }\end{array}$ & $\begin{array}{l}\text { The program seeks to not only offset conventionally } \\
\text { generated electricity, but also to increase community } \\
\text { awareness of renewables. }\end{array}$ \\
\hline Florida Power \& Light & $\begin{array}{l}\text { FP\&L is planning a voluntary, grid-connected PV green- } \\
\text { pricing program for both residential and commercial } \\
\text { customers. }\end{array}$ & The program is on hold due to restructuring \\
\hline Gainesville Regional Utilities & $\begin{array}{l}\text { The GRU Solar project is a voluntary contribution program } \\
\text { to fund a } 10-20-\mathrm{kW} \text { PV project. The PV system will power } \\
\text { the electric system control center and is in part an R\&D } \\
\text { project to demonstrate the use of a PV system at a facility } \\
\text { with existing power conditioning and storage equipment. }\end{array}$ & $\begin{array}{l}\text { Federal funding is being provided through the Utility } \\
\text { Photovoltaic Group's TEAM-UP effort. } 1,600 \text { of } \\
65,000 \text { customers participate with an average contribution } \\
\text { of } \$ 3.32 \text { per month (Westphal 1995). }\end{array}$ \\
\hline Gulf Power & $\begin{array}{l}\text { Gulf Power will be implementing its version of the Solar for } \\
\text { Schools program called "Solmates" sometime in } 1996 . \\
\text { "Solmates" is a voluntary contribution program in which } \\
\text { passive solar, solar thermal, and PV installations, both grid- } \\
\text { connected and stand-alone, will be installed in area schools. }\end{array}$ & \\
\hline MECo & $\begin{array}{l}\text { A green-pricing program of } 1 \text { cent } / \mathrm{kWh} \text { is planned but on } \\
\text { hold due to utility restructuring. }\end{array}$ & \\
\hline
\end{tabular}

Source: Constructed by authors using data from citations in text of table. 


\section{Traverse City Light \& Power}

Traverse City Light and Power (TCL\&P) was thefirst U.S. utility to develop a green-pricing program to promote wind energy development. In 1993, TCL\&P received a \$50,000 grant from the Michigan Public Service Commission to fund wind energy development. At that point, the utility did not need any new generating capacity and did not want to raise rates, but the utility was looking for a revenue-neutral way to meet customer desire for cleaner power. This resulted in a green-pricing program, partially funded by the PSC grant, to finance development of wind energy.

The TCL\&P green-pricing program began in the spring of 1996. Under this program, both residential and commercial customers pay a $1.58 \mathrm{c} / \mathrm{kWh}$ premium to subsidize the development and operation of a $600-\mathrm{kW}$, gridconnected wind turbine in the community. This translates into an increase of $\$ 7.58$ per month on average for residential customers and an increase of between $\$ 17$ and $\$ 23$ per month for commercial customers. Residential customers are asked to make a 3-year commitment and commercial customers a 10-year commitment. Participants are guaranteed that their rates will not increase due to fuel-cost increases during the period in which they are participants. TCL\&P is also considering giving customers a sticker to place on a window or door of their homes or businesses to show their participation in the program.

Only informal market research was undertaken for the planning of this project. The rationale for not conducting formal market research was that the utility wanted to focus on promoting and implementing the program, rather than gathering information on customer interest in the program. The utility was hoping to attract 150-200 customers, but the program is already oversubscribed. As of fall 1995, 245 residential and 18 commercial customers had signed up for the program (Smiley 1995).

\section{Detroit Edison}

Detroit Edison's "Solar Currents" program offers residential and small commercial customers the option of paying an average premium of $\$ 6.59$ per month for each 100 watts of service from a planned 28.4-kW PV facility. DE offered its SolarCurrents program to 300 customers selected at random. Of these, 94 requested information; 4 requested contracts; and 1 retumed a signed contract. The utility originally believed that this response was poor and questioned the accuracy of the market research; however, they are continuing with the program because by mid-November 1995, the utility had received 94 signed contracts (Energy Services Marketing Letter 1995), and as of late January 1996, 248 residential and commercial customers had signed up for the program, with yet others on a waiting list. Residential customers are asked to subscribe for a 2-year period and commercial customers for a 10-year period, although, unlike residential customers, commercial customers have an option to terminate the agreement. The PV installation began operating in May 1996 (The Solar Letter 1996).

\section{Utility PhotoVoltaic Group}

Utility PhotoVoltaic Group (UPVG), a government-industry partnership, designed a "PV Friendly" pricing program in which eight utilities will participate. A total of $347 \mathrm{~kW}$ of PV systems will be installed on more than 100 residential and commercial buildings as a result of this project. The participating utilities are the City of Anaheim (CA), the City of Austin (TX) Electric Utility, Arizona Public Service Company, Central \& Southwest Services (TX), Detroit Edison Company (MI), New York State Electric \& Gas, Northern States Power Company $(\mathrm{MN})$, and Wisconsin Public Service Company. This project was undertaken to validate the results of the market research already completed at each of the utilities showing customer WTP for renewable electricity (National Renewable Energy Laboratory and Photovoltaics for Utilities 1995).

Each utility in the PV Friendly Program will implement its own pricing scheme and program. Thus far, Detroit Edison has released details on its "SolarCurrents" program. Details on the other utilities' programs have not yet 
been released, except that Arizona Public Service Company's project will consist of $17 \mathrm{~kW}$ of residential PV systems (National Renewable Energy Laboratory and Photovoltaics for Utilities 1995).

\section{Public Service Company of Colorado}

PSCo conducted market research to test interest in green pricing in 1992 and began the REAP in October 1993. The program, now called the Renewable Energy Trust (RET), is a contribution type of program in which customers can pledge a monthly amount of their choosing, a one-time payment, or a contribution based on rounding up their monthly electric bill to the nearest dollar. The funds generated from these activities go into the RET, and are used to fund small renewable energy projects. Approximately $\$ 158,000$ has been collected per year and has been used to purchase small non-grid-connected PV projects (Denver Post 1996). As of mid-1996, 14,000 of approximately 870,000 residential customers (1.6\%) participated in the program, pledging an average of $\$ 2$ per month.

Based on the original market research, PSCo was expecting a 10\% participation rate. To increase program participation PSCo concluded that there are two possible options (Butler 1995). The first option would be to undertake a massive public awareness campaign to educate customers on the benefits of renewables and why they should participate in such a program. This method is generally expensive and without short-term returns. Therefore, PSCo is investigating the second option, which is to engage in target marketing. Target marketing involves identifying those customers with more education on renewables and environmental issues and possibly more interest in participating based on involvement with environmental organizations. In addition, during 1996, PSCo is conducting additional market research on customer response to specific renewables products.

\section{Wholesale Customer Programs}

Table 7 briefly summarizes the following two wholesale customer programs.

\section{Portland General Electric}

While residential and small commercial customers are the customer groups most often targeted for green-pricing programs, some utilities have designed programs for large wholesale and industrial customers. In addition to its pilot efforts towards residential customers as previously described. PGE also designed a green-power product for its large wholesale customers, which is a special tariff for a blend of green and conventional power. Two wind projects (which have been contracted for) will supply the green power. Thus far, PGE has signed one contract with the City of Portland, which will purchase 11.2 million $\mathrm{kWh}$, or $5 \%$ of its total municipal power consumption, from the wind projects. The city expects to save $\$ 850,000$ during a 5-five year period of this contract (Ohrenschall and Tansey 1995).

\section{Bonneville Power Administration}

Bonneville Power Administration (BPA) is another utility involved in green-power efforts aimed at large wholesale customers. BPA developed a green-power product that it is marketing to the public utility districts it serves. The program was set up to fund two wind and two geothermal projects that most likely would have been abandoned otherwise. Customers are offered a 20-year fixed contract in which they can choose the resource mix from the four projects (Darr 1995).

Salem Electric Cooperative was the first to contract with BPA for this green-power product and will purchase 7 average MW of power at $35 \mathrm{mills} / \mathrm{kWh}$. The board of directors of Salem Electric Cooperative set a goal to have $17 \%$ of the utility's load served by renewable energy projects, prompting the deal with BPA (The Oregonian 1996). When added to the balance of the hydroelectric supply, $100 \%$ of Salem's power will be renewable. 
Table 7. Wholesale Customer Green-Pricing Programs

\begin{tabular}{lll}
\hline \multicolumn{1}{c}{ Utility } & \multicolumn{1}{c}{ Program } & \multicolumn{1}{c}{ Notes } \\
\hline Portland General Electric & $\begin{array}{l}\text { A special tariff for a blend of green and } \\
\text { conventional power is being marketed to large } \\
\text { wholesale and industrial customers. Two wind } \\
\text { projects that PGE has contracted for will } \\
\text { supply the renewable power-a 12.5-MW }\end{array}$ & $\begin{array}{l}\text { Thus far, the City of Portland has signed a } \\
\text { contract to purchase 11.2 million kWh of green } \\
\text { power during a 5-year period. This amounts to } \\
\text { approximately 5\% of the city of Portland's total } \\
\text { power consumption. The city expects to save }\end{array}$ \\
& $\begin{array}{l}\text { Columbia Hills project and a 25-MW Vansycle } \\
\text { Ridge project. }\end{array}$ & $\begin{array}{l}\text { \$850,000 during the 5-year period as a result of } \\
\text { this contract (Ohrenschall and Tansey 1995). }\end{array}$ \\
& $\begin{array}{l}\text { A green-power product is being marketed to the } \\
\text { public utility districts BPA serves. The } \\
\text { program was set up to fund two wind and two } \\
\text { geothermal projects. }\end{array}$ & $\begin{array}{l}\text { A contract was signed with Salem Electric } \\
\text { Cooperative to provide 7 average MW of green } \\
\text { energy at 35 mills per/kWh. This agreement } \\
\text { was made after the directors of Salem set a goal } \\
\text { to have 17\% of the utility's load served by } \\
\text { renewable energy projects (Darr 1995; }\end{array}$ \\
& & Oregonian 1996). \\
\hline
\end{tabular}

Source: Constructed by authors using data from citations in text of table. 


\section{Other Green-Pricing Programs}

Many other utilities are in various stages of green-pricing programs as well. These include Southern California Edison, Florida Power Corporation, Florida Power \& Light, Gulf Power (FL), Massachusetts Electric Company, Niagara Mohawk (NY), Snohomish County Public Utilities District (WA), Texas Utilities Electric, Ontario Hydro, and Wisconsin Electric. The programs and pricing schemes for the planned or implemented programs of these utilities are as varied as the examples described. Some of these utilities have programs underway, while others are in the research and planning stages. 


\section{Conclusions and Implications for Program Design and Future Research}

Given the limited experience with green-pricing programs accumulated so far, the evidence suggests that programs in which customers pay a monthly premium for a specific renewable electricity product elicit a higher monthly financial commitment per customer than programs asking for contributions to unspecified future actions involving renewables. Table 8 summarizes the results from the three product-specific and two contribution programs for which data were available, contrasting participation, average amount paid per month, and kilowatt output. For residential programs in progress, the actual monthly payment is notably larger in product-specific programs in which customers pay a premium than in programs in which customers contribute amounts of their choosing to unspecified projects. However, to date the number of participants tends to be larger in the contribution-type programs. This has occurred, at least in part, because the product-specific programs have limited participation; these programs all have waiting lists of customers wanting to participate.

Although experience with green pricing is still limited, some important implications for future research and design of green-pricing programs can be gleaned from the work accomplished to date. The questions facing utility planners about green pricing are: How many will subscribe, at what price, and for what products? (Green Pricing Newsletter 1995). Research shows that widespread customer interest is a given. Data from market research show that, although a willingness to pay more for renewable electricity is expressed, less than $10 \%$ will actually pay an increased monthly cost, at least initially (Marcus et al. 1995; Baugh, Byrnes, and Jones 1992).

Why a difference exists between expressed and actual WTP is still unclear. Some hypotheses are that

- $\quad$ Customers' level of trust in their utility might interfere with their WTP (Marcus et al. 1995); customers mayrespond better to programs offered by municipal utilities rather than investor-owned utilities (Marcus et al. 1995)

- Customer segments may vary in WTP, although the evidence for this is scanty (some evidence is mentioned by Baugh, Bymes, and Jones 1992). Although "green" customers may have higher adoption probabilities than others for renewables and emission-allowance programs, the available research findings are mixed and inconsistent on the relationship between WTP and demographic variables such as income, age, political orientation, and education. Nevertheless, some utility market research has limited sampling and data collection to certain segments of utility-service-area populations thereby potentially limiting the pool of potential participants in green-pricing programs.

- It may take a longer time for these programs to "mature" and penetrate the market than was originally expected by utility market researchers.

While these factors have been posited to affect customer participation in green-pricing programs, program features may influence customer response as well. Customers are more likely to participate the more they perceive programs as being:

- $\quad$ Effective in actually producing clean electricity, thus benefitting the environment (Weijo and Boleyn 1996; Bupp and Gorman 1995; Sacramento Municipal Utility District 1995; Green Pricing Newsletter 1995; Baugh, Byrnes, and Jones 1992)

- Directly advantageous: not too expensive to participate; pay small amounts; pay even dollars (Weijo and Boleyn 1996; Green Pricing Newsletter 1995; Bauman 1994; Baugh, Byrnes, and Jones 1992); tax deductible (Weijo and Boleyn 1996); get retum or profit; good investment (Weijo and Boleyn 1996); plan for the future; for children's future (Baugh, Bymes, and Jones 1992); and avoid resource depletion (Harmon and Wind 1995; Baugh, Bymes, and Jones 1992) 
Table 8. Average Monthly Amounts Paid and Kilowatt Production, Product-Specific v. Contribution Green-Pricing Programs, 1996

\begin{tabular}{lclc}
\hline Utility & Number of Participants & $\begin{array}{l}\text { Amount of Payment/ } \\
\text { Contribution Per Month }\end{array}$ & kW of Renewables Installed \\
\hline $\begin{array}{l}\text { Product-Specific Programs } \\
\begin{array}{l}\text { Sacramento Municipal Utility } \\
\text { District }\end{array}\end{array}$ & 350 & $\$ 4.00$ & 1216 \\
$\begin{array}{l}\text { Detroit Edison } \\
\text { Traverse City Light \& Power }\end{array}$ & 248 & $\$ 6.59 / 100$ watts & 28.4 \\
Contribution Programs & 200 & $\$ 7.50(1.58 \phi / \mathrm{kWh})$ & 600 \\
$\begin{array}{l}\text { Gainesville Regional Utilities } \\
\text { Public Service Company of }\end{array}$ & 1,600 & $\$ 3.32$ on average & $10-15$ \\
\hline Colorado & 14,000 & $\$ 2.00$ on average & Small remote photovoltaic systems \\
\hline
\end{tabular}

Source: Constructed by authors using data from citations provided in Table 6. 
- $\quad$ Reduce customer risk: stability, consistency of long-term fixed rates (Weijo and Boleyn 1996; Bauman 1994; Osborn and Collier 1994; Green Pricing Newsletter 1995); customer and utility share the risk (Baugh, Bymes, and Jones 1992); flexibility (cancelable, renewable, transferable); voluntary program (Weijo and Boleyn 1996; Green Pricing Newsletter 1995)

- $\quad$ Simple, easy to understand (Weijo and Boleyn 1996).

Because customers appear to respond more positively to programs that are well defined and tangible, utilities should be as specific as possible when designing and marketing a green-pricing program. Several utilities contacted said that programs focusing on a well-defined renewable energy project are apt to be more successful in gaining a higher level of customer cost commitment than those that are aimed at developing renewables in general. For example, the positive response by customers to SMUD's PV Pioneers Program seems to result, in part, from the fact that they can easily grasp and understand it. Once customers are aware of a program, based on the specificity of information they receive regarding what the program is intended to do, what is expected of them, and what the benefits of participating are, more of them may elect to participate. Utilities can add value by adding attributes, such as rate freezing, that further reduce perceived risk.

Flexibility can contribute to greater program success. Utilities should tailor their program to the needs of various customer groups because different customer groups perceive different value from various program elements. For example, residential customers may find it attractive if a utility can guarantee that rates will not increase due to fuel-cost increases, as in the case of Traverse City Light \& Power's program. On the other hand, some large wholesale customers may perceive more value from a program that offers a competitive price, as Bonneville Power Administration's (BPA) green-power product does. In each case, the utility tailored the program to meet the special needs of each customer group.

The name of the green-pricing program may affect participation levels. SMUD's "PV Pioneer" program label seems to have broad appeal. The evolution of PSCo's program name from "green-pricing" to "Eco-Option" to "Voluntary Renewable Energy Program" to "Renewable Energy Trust" underscores the potential importance of program name. With each name change, participation in PSCo's program increased.

Public education is an important element in program success. The market research to date shows that consumers know little about how their electricity is generated and what the options for generation are (Green Pricing Newsletter 1995). Because customers tend not to think systemically about elecricity generation primarily using coal and nuclear energy, they are hampered in evaluating the conribution of renewables to the energy mix. Public education is needed on energy mixes currently used and specific renewable resources that are available; programs already in place to deploy renewables; costs and benefits of renewables; and why utilities need to charge more for them.

How customers feel about their utility company could also influence their response to both market research questions and to green-pricing programs offered by a utility company. If a utility is trusted, for example, its customers might be more willing to sign on for green-pricing programs. One recent national survey of electricity customers found that about half believed rates were fair, and that their utility company was concerned for its customers (Cambridge Reports/Research International 1994). Just over half considered their utility company "believable." CambridgeReports said that many customers believed their utilities could perform better than they currently were in keeping rates low and in being less harmful to the environment. Other factors could turn customers away from green-pricing programs, including skepticism about utility motives (Energy Services Marketing Letter 1995; Baugh, Bymes, and Jones 1992) and the idea that green marketing is overused, as well as skepticism about whether the program would actually benefit the environment (Baugh, Bymes, and Jones 1992).

Advantages of green pricing to utilities are that such programs can permit a company to differentiate itself from competitors; build customer loyalty; improve relations with customers, regulators, and public interest groups; 
offer products and services that customers want; pursue a policy to reduce environmental pollution and expand the role of renewables; and use market solutions to achieve public policy goals, when possible (Green Pricing Newsletter 1995). One important barrier could be administrative costs, such as the cost of reprogramming the utility's billing system (on the order of $\$ 50,000$ to $\$ 100,000$ at one utility) to accommodate green-pricing mechanisms such as round-up programs (Weijo and Boleyn 1996).

Time is another crucial variable. Most of the experience with green pricing suggests that participation on the order of 1\%-2\% will occur within 2 years of program start-up. However, this level of participation is enough to get programs started. Participation will subsequently grow, but programs have not been around long enough to predict how quickly. Useful future research will focus on testing various product configurations and tailoring products to the specific interests of likely residential, business, and industrial customers.

Innovators, such as SMUD's PV Pioneers, and early adopters choosing to participate in renewables programs can pave the way for more rapid increases in the generation of renewable electricity. These opinion leaders will help to more quickly institutionalize renewable electricity across the country by stimulating customer demand and utility interest in meeting market expectations that utilities are only beginning to understand are genuinely there. 


\section{References}

Baugh, KA., B. Bymes, and C.V. Jones. 1994. "Developing a Customer Driven Renewable Program: Public Service Company of Colorado's Use of Market Research Findings." 6th Biennial Marketing Research Symposium. EPRI TR-104558. Palo Alto, CA: Electric Power Research Institute. 55-68.

Baugh, KA., B.L. Bymes, and C.V. Jones. 1992. " 'Green Pricing' Research: The Renewable Option." Paper presented at a meeting of the National Association of Regulatory Utility Commissioners, Savannah, GA.

Bauman, G.A. (Niagara Mohawk Power Corporation). 1994. Communication to John J. Kelliher, State of New York Department of Public Service, Thirty-Sixth Revised Leave No. 3., November 17.

Breglio, V.J. 1994. Energy-Post-Election Views. RSM, Inc., Lanham, MD.

Bupp, I.C. and J.W. Gorman. 1995. U.S. Public Opinion and the Electric Power Industry: Challenges of Competition. Cambridge, MA: Cambridge Energy Research Associates and Opinion Dynamics Corporation.

Bymes, B., M. Rahimzadeh, K Baugh, and C. Jones. 1995. "Caution: Renewable Energy Fog Ahead! Shedding Light on the Marketability of Renewables." Paper presented at Profits in the Public Interest: NARUCDOE Conference on Renewable and Sustainable Energy Strategies in a Competitive Market, Madison, WI, May 7-10.

Cambridge Reports/Research International. 1994. Earning Residential Customer Loyalty through Environmental Stewardship. Prepared for the Edison Electric Institute, Washington, D.C.

Darr, G. (Bonneville Power Administration). 1995. Personal communication with Ashley Houston. October 4.

Denver Post. 1996. " 'Green Energy' An Option." June 19. p. 1.

Dunlap, R.E. 1991. "Trends in Public Opinion Toward Environmental Issues: 1965-1990." Society and Natural Resources 4:285-312.

Dunlap, R.E. and R. Scarce. 1991. "Trends: Environmental Problems and Protection." Public Opinion Quarterly 55:651-72.

Electrical World. 1993. “Will Customers Pay for Renewables? PSC Launches ‘Green-Power’ Program.” 207 : (10) 19-20.

Energy Services Marketing Letter. 1995. "Green Pricing Programs Receive a Mixed Customer Reception." $1(5): 1,6$.

Farhar, B.C. 1993. Trends in Public Perceptions and Preferences on Energy and Environmental Policy. NREL/TP-461-4857. Golden, CO: National Renewable Energy Laboratory, 376 pp.

Farhar, B.C. 1994. "Trends in U.S. Public Perceptions and Preferences on Energy and Environmental Policy," Annual Review of Energy and the Environment 19: 211-39.

Farhar, B.C. and A.H. Houston. 1996. "Willingness to Pay for Electricity from Renewable Energy." Paper presented at the 1996 Summer Study of the American Council for an Energy-Efficient Economy, Pacific Grove, CA, August. 
Farhar, B.C., C.T. Unseld, R. Vories, and R. Crews. 1980. "Public Opinion about Energy," Annual Review of Energy 5: 141-72.

Farhar, B.C., P. Weis, C. T. Unseld, and B. Burns. 1979. Public Opinion About Energy: A Literature Review. SERITR-53-155. Golden, CO: Solar Energy Research Institute, 450 pp.

Gainesville Regional Utilities. 1991. Report on the Customer Energy Planning Study. Gainesville, FL.

Green Pricing Newsletter. 1995. (2) May. Gardiner, ME: The Regulatory Assistance Project.

Green Pricing Newsletter. 1994. (1) October. Gardiner, ME: The Regulatory Assistance Project.

Harmon, R. and F. Wind 1995. Wind Energy, Creating a Sustainable Economic Base for the Dakotas. Office of Intergovemmental Assistance Poll, Bureau of Government Affairs, Grand Forks, ND. (September)

Marcus, W.B., J.E. Helmich, G.M. Schilberg, J.A. Nahigian, and G.A. Ruszovan. 1995. Photovoltaic Regulatory and Policy Issues. West Sacramento, CA: JBS Energy, Inc.

Market Strategies, Inc. 1991. Customer Opinion Survey. Report for Florida Power Corporation.

McCorkle, S. (Sacramento Municipal Utility District). 1996. Personal communication with Ashley Houston. February 7.

Moskovitz, D. 1993. Green Pricing: Experience and Lessons Learned. Gardiner, ME: Regulatory Assistance Project.

Nakarado, G.L. 1995. "A Marketing Orientation is the Key to a Sustainable Energy Future." White paper. Golden, CO: National Renewable Energy Laboratory.

National Opinion Research Center. 1994. General Social Survey 1994. Chicago, IL: NORC.

National Renewable Energy Laboratory and Photovoltaics for Utilities. 1995. Integrating Renewable Energy for Colorado: New Opportunities in a Changing Utility Industry. Golden, CO.

Niagara MohawkPower Corporation. 1995. Green Pricing Program General Brochure Copy Test. Syracuse, NY.

Ohrenschall, M. and B. Tansey. 1995. "PGE, City of Portland Make a Deal: Power Purchase Contract Specifies Wind Power." Conservation Monitor, July/August, 3.

Oregonian. 1996. "Green Power Makes Sense," page B6, January 22.

Osborn, D.E. and D. Collier. 1996. "The Sustained Orderly Development of Utility, Grid-Connected Photovoltaics." Paper presented at the First International Conference on Solar Electric Buildings, Boston, MA. March.

Osborn, D.E. and D. Collier. 1994. "Utility Commercialization of Grid-Connected Photovoltaics." Paper presented at the ENEL Conference on Modular PV Plant for Multi-Megawatt Power Generation, Paestum, Italy, July.

Sacramento Municipal Utility District. 1995. “Achieving Municipal Power Goals in a Competitive Age.” 1995 Integrated Resource Plan. IV: 1-59. 
Schulze, W.D. 1994. "Green Pricing: Solutions for the Potential Free-Rider Problem." Boulder, CO: University of Colorado.

Smiley, S. (Bay Energy Services). 1995. Personal communication with Ashley Houston. October 10.

The Solar Letter. 1995. "Two of Five Americans Willing to Pay 30\% Premium for Solar Electricity: CERA." 5(13) May 26. 175.

The Solar Letter. 1996. "Michigan Utility Nearly Fully Subscribed For 'Green-Pricing' Solar-Energy Program." 6 (1) January 5. 5-6.

Sustainable Energy Budget Coalition. 1996. America Speaks Out on Energy: A Survey of Public Attitudes on Sustainable Energy Issues. Takoma Park, MD. (Prepared by Ron Hinckley, Research/Strategy/ Management, Inc.)

Van Mierlo, B.C. and C.A. Westra. 1994. "Social Introduction of Grid-Connected Solar Cell Systems into Dutch Housing. The Heerhugowaard Case." 12th European Photovoltaic Solar Energy Conference. Volume II. Bedford, U.K.: H.S. Stephens. 1133-1136.

Van Mierlo, B.C. and C.A. Westra. "Attitude of Occupants Towards Utility Owned PV-Systems." 13th European Photovoltaic Solar Energy Conference. Bedford, U.K.: H.S. Stephens.

Wind Energy Weekly. 1995. Washington, D.C.: The Weekly Newsletter of the American Wind Energy Association. 14 (647) : 1-6.

Weijo, R.O. and D. Boleyn. 1996, "Product Concept and Field Test of Green Marketing Programs," (Draft), paper to be presented at the American Council for an Energy-Efficient Economy 1996 Summer Study, Portland, OR: Portland General Electric.

Westphal, R. (Gainesville Regional Utilities). 1995. Personal communication with Ashley Houston. October 5.

The Wirthlin Group. 1993. Data from Roper Center for Public Opinion Research. G1 McLean, VA. July.

Wood, L.L.; A.E. Kenyon; W.H. Desvousges; L.K Morander. 1995. "How Much Are Customers Willing to Pay for Improvements in Health and Environmental Quality?" Electricity Journal (8:4); pp. 70-77. 


\section{Endnotes}

1. Survey items addressing behavioral responses to environmental protection are those asking about people's recycling behavior, thermostat settings, use of mass transit, and the like.

2. According to Woodet al. (1995), this study used conjoint analysis rather than the contingent valuation (CV) approach to reduce the potential bias in the latter method to under- or over-report "true WTP", depending on question wording.

3. A probability model that accounts for the ordinal nature of the dependent variable. Wood et al. (1995, p. 72) selected this approach rather than contingent valuation because of what they saw as potential bias to under- or over-report "true WTP" depending on question wording.

4. Based on the market research, MECo has planned a green rate at $1 \notin / \mathrm{kWh}$ over base rate, but as of May 1996, the program was on hold because of uncertainty about restructuring.

5. These 24 utilities include Arizona Public Service Company, Sacramento Municipal Utility District (CA), Southem Califomia Edison, Public Service Company of Colorado, Aspen Municipal Electric System (CO), Florida Power Corporation, Florida Power and Light, Gulf Power (FL), Gainesville Regional Utilities (FL), Massachusetts Electric Company, Detroit Edison (MI), Traverse City Light and Power (MI), Niagara Mohawk (NY), Portland General Electric (OR), Bonneville Power Administration (OR), Snohomish County Public Utility District (WA), Ontario Hydro, City of Austin Electric Utility (TX), City of Anaheim (CA), Central and Southwest Services (TX), New York State Electric and Gas, Northern States Power (MN), Wisconsin Public Service, and Texas Utilities Electric. 
